\title{
Research on Storage Capacity Design of Binzhou Port LNG Receiving Station
}

\author{
Xiujun Nie, Qinghui Yuan, Xia Zhao, Xiuyan Zhang \\ Binzhou Polytechnic, Binzhou 256603, China \\ jshnie16@163.com
}

Keywords: Binzhou Port; Liquefied Natural Gas; Receiving Station; Storage Capacity

\begin{abstract}
The completion of Binzhou Port has created conditions for LNG receiving station. The storage capacity and the number of storage tanks in the LNG receiving station are the key parameters of the construction control. After a comparative analysis of the calculation formulas of storage capacity in Europe, Japan and China, the storage capacity of Binzhou Port Receiving Station was calculated basing on the commissioning date of the first phase and the second phase by using the Chinese calculation formula. According to the capacity of four individual tanks, the number of storage tanks is finally obtained, i.e.,3 for the first phase, 5 and 4 for the second phase. It forecasts the construction scale of Binzhou Port LNG Receiving Station and provides the reference scheme.
\end{abstract}

\section{Introduction}

Liquefied Natural Gas(LNG) is mainly composed of methane [1]. It is a kind of clean, efficient and environmentally friendly new energy source and is currently popular around the world. It is generally manufactured according to the standards of American Petroleum Institute, which means the gaseous liquefied gas will be converted to liquid state under the ultra-low temperature environment $\left(-162^{\circ} \mathrm{C}\right)$. LNG has its unique advantages. Compared to gaseous natural gas, it has much smaller volume and accounts for about half of the volume of water. It is colorless, tasteless, nontoxic and non-corrosive.

Natural gas is widely used. At present, the world annual demand for natural gas exceeds 25000000 tons, of which $1 / 3$ are internationally traded in liquid state. The global demand for natural gas is expected to increase to 40000000 tons by 2030, with an estimated growth rate of $60 \%$ and an average annual growth rate of $5 \%$. At the same time, the global demand for LNG is expected to reach 410000000 tons by 2020 which is 100000000 tons more than 310000000 tons in 2015 and grow at an average annual rate of 20000000 tons.

Because of the global demand for LNG, the construction of LNG receiving station has also become the focus of global attention. By 2020, global investment on LNG receiving stations is expected to increase substantially. The investment of LNG equipment in North America is about 35000000000 dollars, while China will invest more than 60000000000 yuan in LNG receiving terminal.

\section{General Situation of Binzhou Port Construction}

Binzhou Port is the only port of cargo import and export in northwestern Shandong Province. It is located in the Beihai New District of Binzhou City, the Yellow River Delta Basin, the northern coast of Shandong Peninsula. Its geographic position is between 37' $\mathrm{N}$ and 117'E, i.e. southwestern coast of Bohai Bay. Binzhou Port is opposite Huanghua in Hebei Province and Tianjin with Bohai Bay in between. The design annual throughput is 3000000 tons. 


\section{Necessity of Binzhou Port LNG Receiving Station Construction}

\subsection{The Opening of LNG Shipping Construction Era}

In order to protect the marine environment, International Convention for the Prevention of Pollution from Ships(MARPOL) was promulgated and implemented by the International Maritime Organization in 1973. Low carbon and environmental protection has become the mainstream of global shipping development. Natural gas, as an environmentally friendly fuel, conforms to MARPOL. Chinese shipping has begun to vigorously substitute gas for oil. With the rapid development of LNG power ship industry, the market demand of LNG is increasing, forcing the port to construct LNG receiving station and become the gas station of LNG power ships.

\subsection{Construction and Using of Binzhou Port}

In 2010, Binzhou City clung to the historical opportunity of the development of Yellow River Delta Economic Zone and Blue Shandong Peninsula Economic Zone, and appointed Binzhou Port as the key point of the citywide "No. 1 Project" in 2011. In 2013, the 10000-ton class vessel "Haochang 6" docked in Binzhou Port, which means that the $2 \times 3$ 10000-ton class bulk cargo wharf is open for trial navigation.

After years of development, Shengli Oilfield has been developing rapidly in Binzhou area. The crude oil processing led by Binzhou and Dongying has increased rapidly. Petrochemical industry has become the main industry in the region, playing a stimulating role for Shandong's economic development, especially for its northwest area. Under the premise of environmental protection and ecological development, LNG is favored as a kind of clean fuel. The construction of Binzhou Port LNG Receiving Station will inject new vitality into Binzhou economy and stimulate its overall development.

\subsection{Ocean Department Of Binzhou Polytechnic to Train Talents for Serving the Local Economic Development}

Ocean Department Of Binzhou Polytechnic was set up in 2007 and now has majors such as Navigation, Turbine, Port Management, etc. Having trained a large number of marine personnel and skilled and management personnel for Binzhou Port and LNG ships, Ocean Department Of Binzhou Polytechnic has become the strong personnel backup of Binzhou Port.

\section{Design Calculation of the Number of Storage Tanks of Binzhou Port LNG Receiving Station}

\subsection{Scale of Construction}

The total area of liquid bulk cargo operation zone is about 350 hectares according to the general layout of the port area of Binzhou Port. It is located in the east side of the entrance, planning 13 berths, the capacity of which is up to 100000 -ton class liquid bulk cargo[2].

The total construction scale of the LNG Receiving Station, including Binzhou Port LNG receiving wharf and its supporting project, is to receive and transport 6000000 tons of LNG per year. Among it, the first phase construction is expected to receive and transport 2000000 tons LNG per year,the second phase construction 4000000 tons. Compared with the major LNG receiving stations that have put on production in China, Shenzhen, Guangdong Province and Putian, Fujian Province, etc., it is basically remained at the same level,see Table 1 . The location of the liquid chemical wharf is shown in Pig. 1. 
Table 1 Major LNG Receiving Stations That Have Put on Production in China

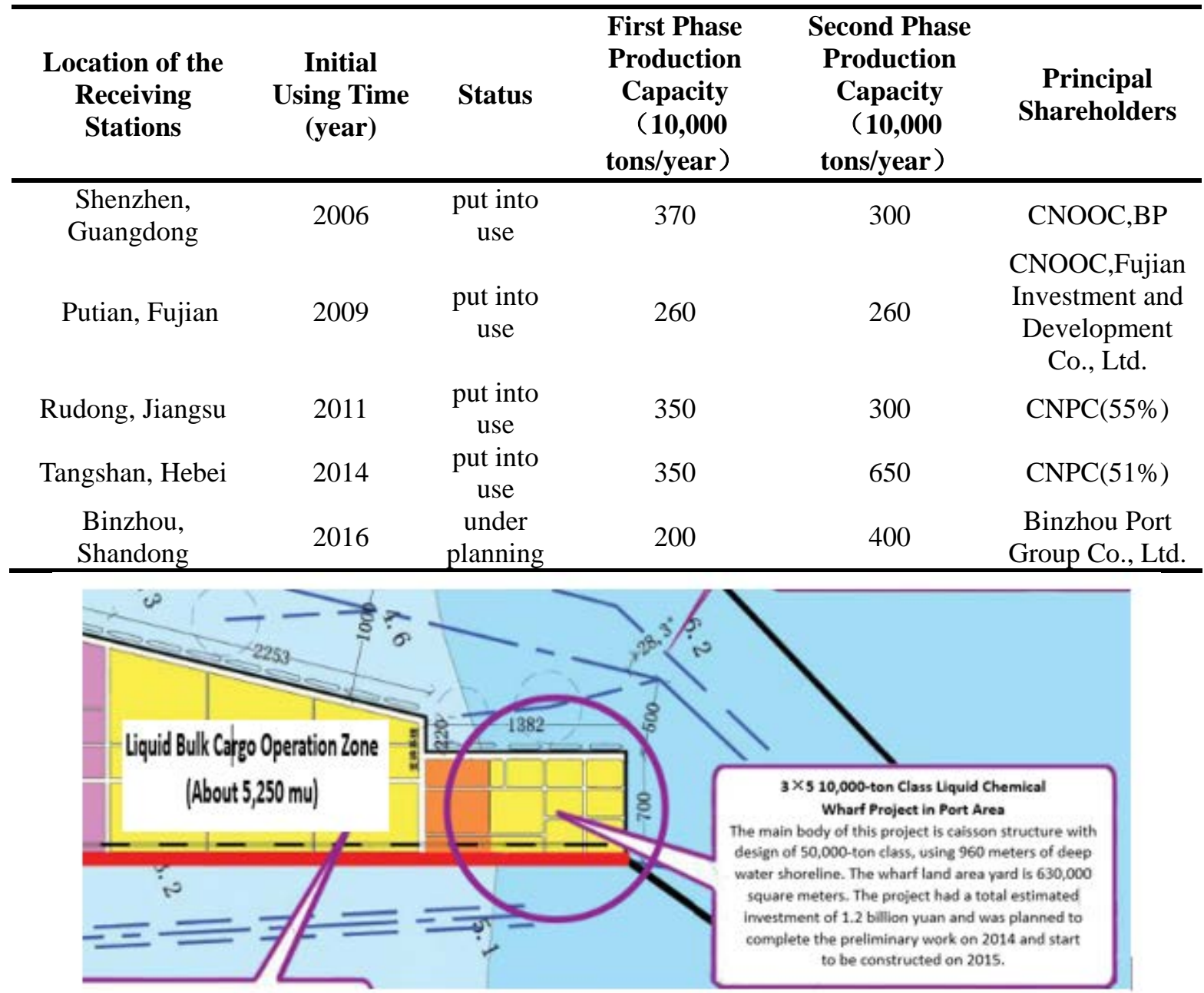

Fig. 1 Location of the Liquid Chemical Wharf

\subsection{Design Calculation of the Number of Storage Tanks}

At present, the LNG storage tanks in China are mainly land storage tanks, while the underground tanks are largely used in Japan considering the special factors of earthquake safety. [3]Binzhou Port is located in the Bohai Bay. Considering the current situation of our LNG construction and the saline-alkali land, the storage tanks in this project were designed as land storage tanks.

The receiving station takes on the role of seasonal peak-shaving. The storage capacity of the LNG receiving station is related to the effective capacity of the LNG transport ships, the safety margin of storage during the maximum non-operational period, the storage capacity to meet the peak shaving task, the upstream LNG shipping arrangements and other planned or unforeseen events, such as the delay or maintenance of the LNG transport ships , climate change, etc.

The formulas for calculating the storage capacity of the receiving station are not the same all over the world. In Europe, it is generally adopted that the LNG receiving stations do not undertake seasonal peak shaving, but use underground gas storage to adjust the peak of gas used in the market. The advantage of this calculation formula is that it does not deal with the problem of peak shaving and ensures the uniformity of the natural gas output from the LNG receiving station. The calculation formula in Europe is shown in Formula 1. The LNG receiving stations in Japan are more mature in the study of peak-shaving, so they usually take on the peak-shaving task. The calculation formula in Japan is shown in Formula 2. Formula 3 [4-7] is adopted in Shenzhen LNG Project in China.

In this paper, Formula 3 is used to calculate the storage capacity of the receiving station and the number of storage tanks. 


$$
\mathrm{Vs}=[\mathrm{Vt}+(\mathrm{n} \times \mathrm{Q})-(\mathrm{t} \times \mathrm{q})] / \mathrm{k}
$$

Among it, "Vs" means the minimum tank capacity required; "Vt" means the maximum capacity to be discharged from a LNG ship; " $n$ " means the maximum non-operational days, and it is generally 5 days; "Q” means the maximum LNG output of the receiving station, including output of the arterial line and the tankers; " $t$ " means the unloading time of the ship; "q" means the minimum LNG output of the receiving station; " $k$ " means the safety factor of tank capacity.

$$
\mathrm{V}=\mathrm{V} 1+\mathrm{V} 2+\mathrm{V} 3+\mathrm{V} 4
$$

Among it, "V" means the LNG tank capacity(m3) of the receiving station; "V1" means the effective loading and unloading capacity of the LNG transport ships; "V2" is the reserve storage, which takes into account the reserve storage of the maximum non-operational period basing on the average reserve storage of 5 days; "V3" means the storage capacity of seasonal peak-shaving $\left(\mathrm{m}^{3}\right)$; "V4" means the stagnant storage capacity, which can be considered as $3 \%$ of the tank capacity $\left(\mathrm{m}^{3}\right)$.

$$
\mathrm{V}=\mathrm{V} 1+\mathrm{V} 2+\mathrm{V} 3
$$

Among it, "V" means the LNG storage capacity(m3) of the receiving station; "V1" means the effective unloading capacity(m3) of the LNG transport ships ; "V2" is the reserve storage, which takes into account the reserve storage of the maximum non-operational period basing on the average reserve storage of 5 days; "V3” means the storage capacity of seasonal peak-shaving $\left(\mathrm{m}^{3}\right)$.

\subsubsection{Calculation of the Storage Capacity of the Receiving Station}

\section{(1) Calculation of V1}

In 2005, the capacity of LNG ship was mostly $150000 \mathrm{~m}^{3}$, but now it is between $210000 \mathrm{~m}^{3}$ and $220000 \mathrm{~m}^{3}$, so the design calculation of $\mathrm{V} 1$ is $215000 \mathrm{~m}^{3}$ and the effective ship capacity is $206400 \mathrm{~m}^{3}$.

\section{(2) Calculation of V2}

In Formula 1, 2 and 3, the maximum non-operational days is 5 days according to the international standard, and the calculation formula of the reserve storage is shown in Formula 4. The reserve storage of the first phase and second phase production capacity are calculated respectively, and the results are shown in Table 2.

$$
\text { V2= Annual Demand } / 365 \times 5
$$

The density of LNG is $0.45 \mathrm{t} / \mathrm{m}^{3}$.

Table 2 Calculation of the Reserve Storage of Binzhou Port LNG Receiving Station

\begin{tabular}{ccc}
\hline & $\begin{array}{c}\text { Production Volume } \\
\left(10^{4} \mathrm{t} / \mathrm{a}\right)\end{array}$ & $\begin{array}{c}\text { Reserve Storage } \\
\left(10^{3} \mathrm{~m}^{3}\right)\end{array}$ \\
\hline $\begin{array}{c}\text { First Phase Production } \\
\text { Volume }\end{array}$ & 200 & 60.88 \\
$\begin{array}{c}\text { Second Phase } \\
\text { Production Volume }\end{array}$ & 400 & 121.77 \\
\hline
\end{tabular}

\section{(3) Calculation of V3}

The seasonal peak shaving value is calculated by Formula 5, and the results are shown in Table 3.

$$
\text { V3=Annual Demand } \times \text { Seasonal Peak Shaving Coefficient }
$$

Seasonal Peak Shaving Coefficient $=\Sigma(A-B) \div C$. Among it: A means the monthly demand of peak 
demand period; B means the monthly average demand; $\mathrm{C}$ means the total annual demand.

Table $3 \mathrm{n}$ of the Seasonal Peak Value of Binzhou Port LNG Receiving Station

\begin{tabular}{|c|c|c|}
\hline & $\begin{array}{c}\text { Seasonal Peak Shaving } \\
\text { Coefficient (\%) }\end{array}$ & $\begin{array}{c}\text { Seasonal Peak Value } \\
\left(10^{3} \mathrm{~m}^{3}\right)\end{array}$ \\
\hline $\begin{array}{c}\text { First Phase } \\
\text { Production Volume }\end{array}$ & 7.81 & 156.2 \\
\hline $\begin{array}{c}\text { Second Phase Production } \\
\text { Volume }\end{array}$ & 7.04 & 281.6 \\
\hline
\end{tabular}

\section{(4) Storage Capacity of the Receiving Station}

The above calculation results are substituted in Formula 3, then the storage capacity of the first phase production volume and second phase production volume of Binzhou Port Receiving Station are determined respectively. The results are shown in Table 4.

Table 4 Storage Capacity of Binzhou Port Receiving Station

\begin{tabular}{ccccc}
\hline $\begin{array}{c}\text { Production } \\
\text { Time }\end{array}$ & $\mathrm{V} 1\left(10^{3} \mathrm{~m}^{3}\right)$ & $\mathrm{V} 2\left(10^{3} \mathrm{~m}^{3}\right)$ & $\mathrm{V} 3\left(10^{3} \mathrm{~m}^{3}\right)$ & $\mathrm{V}\left(10^{3} \mathrm{~m}^{3}\right)$ \\
\hline $\begin{array}{c}\text { First Phase } \\
\text { Second } \\
\text { Phase }\end{array}$ & 206.4 & 60.88 & 156.2 & 423.48 \\
\hline
\end{tabular}

\subsubsection{Calculation of the Number of Storage Tanks in the Receiving Station}

In this paper, the storage capacity of LNG Receiving Station in Binzhou Port is calculated without considering the adjustment of sailing date. The capacity of single tank is $150 \mathrm{~m}^{3}$ to $180 \mathrm{~m}^{3}\left(103 \mathrm{~m}^{3}\right)$ respectively. The results are shown in Table 5.

Table 5 Number of the Storage Tanks in Binzhou Port Receiving Station

\begin{tabular}{cccccc}
\hline $\begin{array}{c}\text { Production } \\
\text { Time }\end{array}$ & $\mathrm{V}\left(10^{3} \mathrm{~m}^{3}\right)$ & $150\left(10^{3} \mathrm{~m}^{3}\right)$ & $160\left(10^{3} \mathrm{~m}^{3}\right)$ & $170\left(10^{3} \mathrm{~m}^{3}\right)$ & $180\left(10^{3} \mathrm{~m}^{3}\right)$ \\
\hline $\begin{array}{c}\text { First Phase } \\
\text { Second }\end{array}$ & 423.48 & 3 & 3 & 3 & 3 \\
Phase & 609.77 & 5 & 4 & 4 & 4 \\
\hline
\end{tabular}

\section{Conclusion}

The extensive use of LNG has promoted the opening of the LNG shipping construction era. The two complement each other, increasing the number and scale of LNG receiving stations construction gradually. The special geographical position of the Binzhou Port makes it attractive the LNG receiving stations, and local colleges also make a great contribution to its development by cultivating talents. In this paper, the number of storage tanks in Binzhou Port LNG Receiving Station is calculated by comparing the 3 different storage capacity calculation formulas of the LNG receiving station and using the domestic calculation method to measure the storage capacity of Binzhou Port. Therefore, the construction scale of Binzhou Port LNG Receiving Station is predicted, and a reference program is provided as well.

\section{Acknowledgements}

Research on the construction of LNG terminal in Binzhou port（2014ZC0308）

\section{References}

[1]Industry Standard of People's Republic of China Code for Design of Liquefied Natural Gas Port and Jetty JTS165-5-2016 Ministry of Transport of the People's Republic of China. 
[2]“Master Plan of Binzhou Port(approved draft)" <https://max.book118.com/html/ 2015/0723/21721144.shtm 2015>.

[3]Li Jianhu. "A Review on the Construction of LNG Receiving Station in China, America, and Japan”. Natural Gas Technology.2010,4(2):67-70.

[4]Leng Xulin, Wang Yan,et al. "Calculation Method of Tank Capacity of LNG Receiving Station”. Oil \& Gas Storage and Transportation.2007, 26 (9):17-18.

[5]Sun Qingfeng, Zhao Degui. “Storage tank Configuration of LNG Receiving Station”. Oil \& Gas Storage and Transportation.2009,28(3):17-18,48.

[6]Fu Zihang. “To Calculate the Effective Tank Capacity of LNG Receiving Station by Using Dynamic Logistics Model”. Natural Gas Industry.2010, 30(7):69-72.

[7]Song Pengfei, Li Feng,et al. "Design Calculation of Tank Capacity and Quantity in LNG Receiving Station”. Oi I\& Gas Storage and Transportation. 2015,34(3):316-318, 339. 